\title{
- JAKOŚĆ ŻYCIA I SAMOOCENA PACJENTÓW LECZONYCH NERKOZASTĘPCZO
}

\section{QUALITY OF LIFE AND SELF-ESTEEM OF PATIENTS TREATED WITH RENAL REPLACEMENT THERAPY}

\author{
Magdalena Strugała ${ }^{1}$, Dorota Talarska ${ }^{1}$, Tomasz Niewiadomski ${ }^{2}$, Tomasz Ptaszyński ${ }^{3}$, \\ Paulina Muszyńska ${ }^{4}$, Izabela Wróblewska ${ }^{5}$, Małgorzata Dziechciaż ${ }^{6}$ \\ ${ }^{1}$ Katedra i Zakład Profilaktyki Zdrowotnej \\ Pracownia Pielęgniarstwa Społecznego \\ Uniwersytet Medyczny im. Karola Marcinkowskiego w Poznaniu \\ ${ }^{2}$ Ortopedyczno-Rehabilitacyjny Szpital Kliniczny im. Wiktora Degi \\ Uniwersytet Medyczny im. Karola Marcinkowskiego w Poznaniu \\ ${ }^{3}$ Instytut Psychologii \\ Uniwersytet im. Adama Mickiewicza w Poznaniu \\ ${ }^{4}$ studentka Wydziału Nauk o Zdrowiu \\ Uniwersytet Medyczny im. Karola Marcinkowskiego w Poznaniu \\ ${ }^{5}$ Wydział Nauk o Zdrowiu \\ Uniwersytet Medyczny we Wrocławiu \\ ${ }^{6}$ Państwowa Wyższa Szkoła Techniczno-Ekonomiczna w Jarosławiu
}

DOI: https://doi.org/10.20883/pielpol.2017.15

\section{STRESZCZENIE}

Wstęp. Artykuł przedstawia poziom jakości życia i samooceny pacjentów leczonych metodą hemodializ. Schyłkowa niewydolność nerek (ang. end-stage renal disease - ESRD) oraz jej leczenie wpływa na wszelkie obszary życia chorego, dlatego w badaniu jakości życia (ang. quality of life - QoL) ważna jest analiza determinantów zarówno obiektywnych, jak i subiektywnych.

Cel. Głównym celem pracy było określenie związku jakości życia i samooceny pacjentów leczonych nerkozastępczo.

Materiał i metody. W badaniu wzięło udział 98 pacjentów leczonych metodą hemodializ. Jakość życia pacjentów dializowanych, oceniono zgodnie ze skalą The Kidney Disease Quality of Life (KDQLL), poziom samooceny określono przy wykorzystaniu narzędzia The Rosenberg Self Esteem (SES).

Wyniki. Potwierdzono związek jakości życia z samooceną chorych leczonych nerkozastępczo. Wykazano, że znaczna część badanych miała pozytywną samoocenę.

Wnioski. Uzyskane wyniki stanowią wstęp do dalszych prospektywnych interwencji w celu poprawy jakości życia tej grupy pacjentów.

SŁOWA KLUCZOWE: jakość życia, samoocena, leczenie nerkozastępcze.

\section{Wstęp}

Przewlekła niewydolność nerek (ang. chronic renal disease - CRD) jest zespołem chorobowym przebiegającym z nieodwracalnym uszkodzeniem nerek, przejawia-

\begin{abstract}
Introduction. The article presents the reported quality of life and self-esteem of patients treated with hemodialysis. End-stage renal failure (end-stage renal disease - ESRD) and its treatment affects all spheres of patient's life, which is why the study of quality of life (quality of life - QoL) is important to analyse both objective and subjective determinants.

Aim. The main objective of the study was to determine the relationship of quality of life and self-esteem of patients treated with renal replacement therapy.

Material and methods. The study involved 98 patients treated with hemodialysis. The quality of life of dialysed patients was rated according to The Kidney Disease Quality of Life (KDQoL) scale, the level of self-esteem was determined using the Rosenberg Self-Esteem (SES) questionnaire.

Results. Results confirmed the relationship between self-esteem and quality of life for patients treated with renal replacement therapy. The results indicate that a substantial proportion of respondents had positive self-esteem.

Conclusions. The results serve as preliminary data for further possible interventions to improve quality of life for this group of patients.
\end{abstract}

KEYWORDS: quality of life, self-esteem, renal replacement therapy.

jącym się zaburzeniem czynności wydalniczej nerek W ostatnich latach wśród chorych z CRD wzrasta, głównie na skutek powikłań, odsetek osób wymagających dializoterapii [1, 2]. Schyłkowa niewydolność nerek 
(ang. end-stage renal disease - ESRD) oraz jej leczenie wpływa na wszelkie obszary życia chorego, dlatego w badaniu jakości życia (ang. quality of life - QoL) ważna jest analiza determinantów zarówno obiektywnych, jak i subiektywnych [3].

Ocena QoL zajmuje znaczące miejsce w doniesieniach badawczych. Dzieje się tak z powodu wydłużania się okresu życia, także osób przewlekle chorych. Przykładem mogą być właśnie osoby z ESRD, których jakość życia może zależeć bezpośrednio od stanu klinicznego i funkcjonalnego, a pośrednio również od samooceny [3]. Jakość życia zależna od obecności choroby przewlekłej stanowi ważny element wpływu na terapię, jest ważnym wskaźnikiem zdrowia, gdyż odzwierciedla zdolność chorych w zakresie codziennego funkcjonowania, poczucie satysfakcji z życia i psychicznego dobrostanu, ponadto dostarcza informacji dotyczących postrzegania siebie i samooceny pacjenta przez pryzmat fizycznych, psychicznych, emocjonalnych, społecznych i behawioralnych elementów choroby $[4,5]$. Rzetelna ocena QoL, poprzez szerokie wielowymiarowe podejście, przedstawia korzyści z leczenia i opieki, pozwala ocenić objawy związane z terapią, głównie świadczące o wysokiej uciążliwości procesów związanych z dializoterapią, a mające duży wpływ na samoocenę, np. ciągłe uczucie zmęczenia, osłabienie, bóle głowy, kurcze mięśni, świąd skóry, bezsenność itd. [6, 7]. Najczęstszym sposobem pomiaru QoL są metody kwestionariuszowe, oparte na samoocenie pacjenta. Stąd pożądane jest wykorzystywanie sprofilowanych do danej sytuacji klinicznej narzędzi badawczych jakości życia, takich jak np. skala The Kidney Disease Quality of Life (KDQoL) [6]. Kwestionariusz ten został stworzony do pomiaru typowych, postrzeganych przez pacjenta, problemów związanych ze zdrowiem w przewlekłej niewydolności nerek oraz do oceny wpływu tych problemów na codzienne funkcjonowanie. Niezależnie jednak od tego, jaki zostanie zastosowany kwestionariusz, należy wciąż mieć na uwadze, że jakość życia ma zawsze wymiar indywidualny i zmienia się w czasie.

Zaawansowana choroba nerek, często z powikłaniami i koniecznością częstego odbywania hemodializ, bywa przyczyną ograniczenia życia społecznego, rodzinnego i zawodowego, co ma związek ze zmaganiem się z ciężarem choroby. Postrzeganie siebie jest ważnym punktem odniesienia w ocenie wpływu przewlekłej choroby nerek i jej leczenia na jakość życia chorych. Samoocena jest subiektywnym postrzeganiem siebie, istotnie powiązanym z akceptacją społeczną [8, 9]. Niska samoocena to częsty problem pacjentów dializowanych. Oznacza mniejsze poczucie własnej wartości, zaburzenia akceptacji własnego wizerunku, obniżenie zadowolenia z siebie i społecznych relacji. Przejawia się również brakiem napędu, tendencją do obniżonego nastroju, słabą motywacją do leczenia i zachowań prozdrowotnych czy do ewentualnej zmiany stylu życia [10]. Może wynikać także z braku odpowiedniego wsparcia emocjonalnego czy niskiego poczucia własnej wartości. Osoby charakteryzujące się lepszą samooceną łatwiej radzą sobie z sytuacjami trudnymi, do których należy choroba przewlekła - ESRD [11]. W świetle przeanalizowanej literatury można uznać, że badaniu samooceny w kontekście jakości życia pacjentów dializowanych poświęca się zbyt mało uwagi, a przecież poprawa zadowolenia z siebie, zrozumienie przewlekłej choroby i bardziej optymistyczne jej postrzeganie mają niezaprzeczalnie związek z lepszą jakością życia [12, 13]. Dlatego uznano ten temat za warty pogłębienia poprzez zainicjowanie adekwatnych badań, w których kluczowe znaczenie ma zbadanie relacji wybranych cech socjodemograficznych i klinicznych oraz samooceny względem jakości życia pacjentów z ESRD leczonych dializami.

Celem pracy było określenie związku jakości życia i samooceny pacjentów leczonych nerkozastępczo.

\section{Materiał i metody}

Do badań zakwalifikowano 104 pacjentów leczonych metodą hemodializ na terenie miasta Poznania. Kilku (6) pacjentów odmówiło udziału w badaniu z przyczyn osobistych. Ostatecznie w badaniu wzięło udział 98 chorych.

Czynniki włączenia:

- $\quad$ pacjenci leczeni przynajmniej 6 miesięcy za pomocą hemodializy,

- $\quad$ sprawność psychofizyczna umożliwiająca wypełnienie narzędzi badawczych,

- choroby współistniejące nieograniczające funkcjonowania psychofizycznego,

- brak choroby nowotworowej.

W obrębie całej grupy przyjęto następujący kierunek badań: w pierwszej kolejności przeprowadzono analizę zależności jakości życia z parametrami socjodemograficznymi i samooceną. Następnie zbadano związek poszczególnych domen jakości życia (QoL) z samooceną chorych (SES).

\section{Narzędzia badawcze}

W badaniu zastosowano następujące specyficzne instrumenty:

- The Kidney Disease Quality of Life (KDQoL),

- $\quad$ The Rosenberg Self Esteem (SES).

KDQoL - skala ta nie należy do często stosowanych narzędzi badawczych, mimo iż ma wysokie parametry psychometryczne, wyłonione na podstawie licznych wieloośrodkowych badań, cytowanych w literaturze [7, 
14, 15]. KDQoL, jak wszystkie skale wielowymiarowe, pozwala na dokonanie precyzyjnej indywidualnej oceny jakości życia pacjentów leczonych nerkozastępczo [14]. Dostarcza informacji o pacjencie z zakresu czterech obszarów: zdrowie fizyczne, zdrowie psychiczne, problemy związane z chorobą i satysfakcja z opieki medycznej. W sumie zawiera 24 pytania, które oprócz oceny zdrowia i samopoczucia pacjenta, dotyczą także wydolności w zakresie codziennych czynności życiowych i mobilności. Pytania podzielone są na 11 domen, każda z nich oceniana jest w skali od 0 do 100 punktów. Wyższy wynik oznacza lepszą jakość życia [6, 7].

\section{Domeny KDQoL:}

KDQoL D1 - Objawy

KDQoL D2 - Wpływ choroby nerek

KDQoL D3 - Ciężar choroby nerek

KDQoL D4 - Stan zatrudnienia

KDQoL D6 - Jakość stosunków międzyludzkich

KDQoL D7 - Czynności seksualne

KDQoL D8 - Sen

KDQoL D9 - Wsparcie społeczne

KDQoL D10 - Wsparcie pracowników stacji dializ

KDQoL D11 - Satysfakcja pacjenta

SES - skala samooceny M. Rosenberga, składa się z 10 twierdzeń diagnostycznych, służących do ogólnej samooceny chorego; 5 twierdzeń zawiera pozytywnie sformułowane oświadczenia, a kolejne 5 - negatywnie. Badany ma za zadanie wskazać na 4-stopniowej skali Likerta, w jakim stopniu zgadza się z każdym z tych stwierdzeń. Ogólny wynik zawiera się w przedziale od 10 do 40 punktów, wyższa liczba punktów przemawia za lepszą samooceną respondenta [8, 9].

Opis poszczególnych stwierdzeń w skali przedstawia się następująco:

SES 1 - Uważam, że jestem osoba wartościową przynajmniej w takim samym stopniu, co inni

SES 2 - Uważam, że posiadam wiele pozytywnych cech

SES 3 - Ogólnie biorąc, jestem skłonny sądzić, że nie wiedzie mi się

SES 4 - Potrafię robić różne rzeczy tak dobrze, jak większość innych ludzi SES 5 - Uważam, że nie mam wiele powodów, aby być z siebie dumnym
SES 6 - Lubię siebie SES 7 - Ogólnie rzecz biorąc, jestem z siebie zadowolony

SES 8 - Chciałbym mieć więcej szacunku dla samego siebie

SES 9 - Czasami czuję się bezużyteczny

SES 10 - Niekiedy uważam, że jestem do niczego
Uzupełnieniem powyższych narzędzi, w ramach badań własnych, była metryczka dla projektu: zdrowie, radzenie sobie i jakość życia, umożliwiająca zebranie danych socjodemograficznych oraz informacji na temat stanu zdrowia.

\section{Analiza statystyczna}

Wykorzystano pakiet statystyczny STATISTICA 10 PL. Do oceny różnic między dwoma niezależnymi grupami zastosowano nieparametryczny test Manna-Whitneya, a dla więcej niż dwóch - test Kruskala-Wallisa. Dla określenia zależności między zmiennymi zastosowano współczynnik korelacji rangowej Spearmana. Do analizy zmiennych nominalnych wykorzystano test niezależności chi-kwadrat Pearsona. Wszystkie testy uznawano za istotne statystycznie przy $p<0,05$.

\section{Wyniki}

Cechy socjodemograficznych i przyczyny choroby badanej grupy przedstawiono w tabeli 1.

Tabela 1. Czynniki demograficzne i przyczyny ESRD Table 1. Demographic variables and causes of ESRD

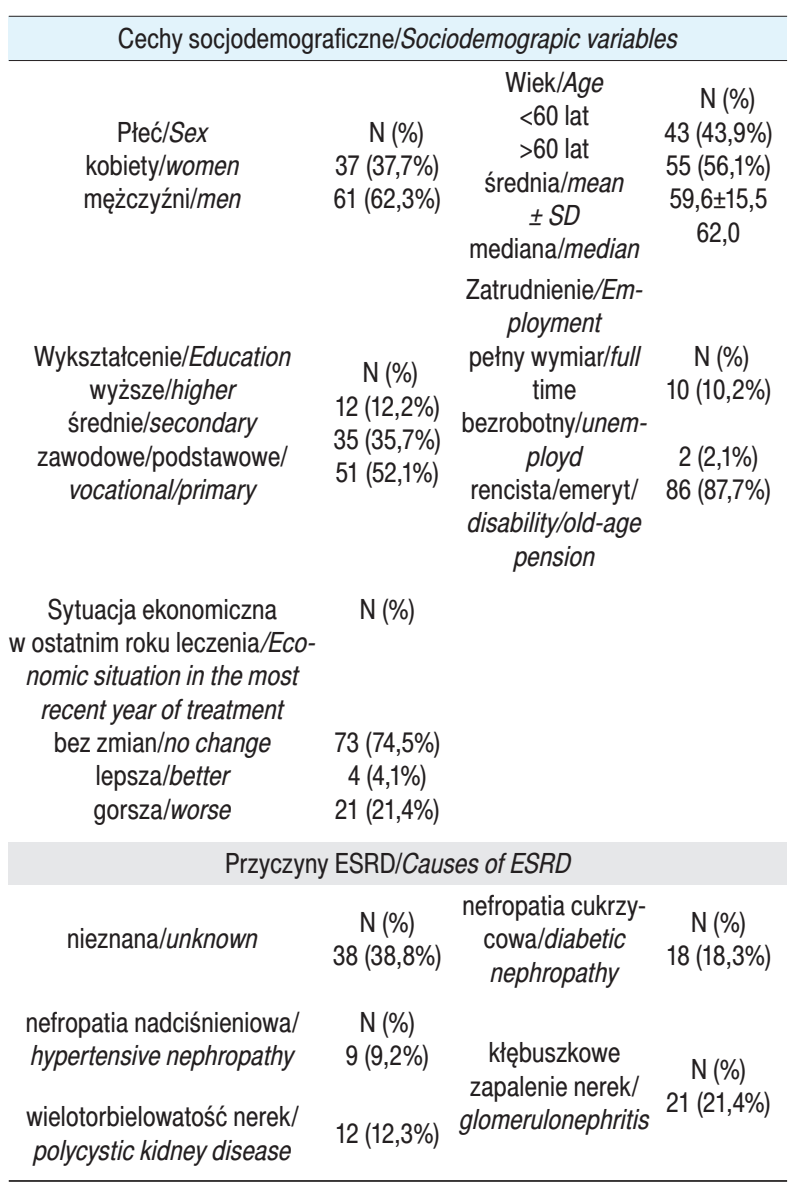

Źródło: opracowanie własne

Source: author's own analysis 


\section{Dane kliniczne}

Średni czas trwania dializ dla całej grupy wynosił 44,7 \pm 48,6 miesiąca, w tym dla kobiet 46,6 \pm 49,1, a dla mężczyzn 42,6 \pm 48,4 miesiąca. Przewlekła choroba nerek najczęściej była konsekwencją: kłębuszkowego zapalenia nerek (21,4\%), nefropatii cukrzycowej (18,3\%), wielotorbielowatości nerek (12,3\%) i nefropatii nadciśnieniowej (9,2\%). Czas, jaki pacjenci przeznaczali na hemodialize wraz z dojazdem, u 57\% grupy wynosił 8-10 godz., a u 43\% respondentów - 5-7 godz.

\section{Wyniki badań laboratoryjnych}

Przebieg procesu leczenia analizowano, opierając się m.in. na poziomie: hemoglobiny, która w badanej grupie wynosiła 10,4 \pm 1,4 g/dl (norma > 11,5 g/dl K, > 13,5 g/dl M), mocznika w surowicy krwi 22,3 $\pm 5,6 \mathrm{mmol} / \mathrm{l}$ (norma 2,46 - 6,66 g/dl), kreatyniny 749,3 $\pm 243,3 \mu \mathrm{mol} / \mathrm{l}$ (norma 62-115 $\mu \mathrm{mol} / \mathrm{l})$. Za pomocą testu Manna-Whitneya potwierdzono różnicę między stężeniem kreatyniny w surowicy krwi u kobiet i mężczyzn $(p<0,021)$. Poziom kreatyniny u mężczyzn był znacznie wyższy.

\section{Wyniki otrzymane z zastosowanych skal}

Wzrost uzyskiwanej przez respondentów wartości punktowej w skalach KDQoL i SES oznaczał lepszą obiektywnie i subiektywnie jakość życia oraz samoocenę.

Parametry socjodemograficzne a KDQoL. Test Manna-Whitneya nie wykazał istotnej statystycznie różnicy między płcią, stanem cywilnym a poszczególnymi domenami KDQoL. Wiek istotnie różnicował jakość stosunków międzyludzkich (KDQoL D6; $p=0,019$ ), aktywność seksualną (KDQoL D7; $p=0,007$ ) oraz wsparcie społeczne (KDQoL D9; $p=0,047)$. Wykształcenie z kolei - stan zatrudnienia (KDQoL D4; $p=0,022$ ) i funkcje poznawcze (KDQoL D5; $p=0,042)$. Natomiast przyczyna choroby nerek w największym stopniu związana była z wpływem choroby nerek na życie (KDQoL D2; $p=0,010)$. Młodsi, lepiej wykształceni, posiadający pracę, a także badani, u których cukrzyca nie była zasadniczą przyczyną niewydolności nerek, lepiej oceniali jakość życia (Tabela 2).

Parametry socjodemograficzne a SES. Istotnie różnicowały samoocenę: stan cywilny ( $p=0,016)$, wykształcenie ( $p=0,001$ ) oraz sytuacja ekonomiczna ( $p=0,003$ ). Osoby w związku, ze średnim i wyższym wykształceniem oraz w stabilnej sytuacji ekonomicznej miały lepszą samoocenę (Tabela 2).
Tabela 2. Ocena KDQoL i SES z uwzględnieniem zmiennych socjodemograficznych i przyczyny choroby

Table 2. KDQoL and SES scores by sociodemographic variables and causes of ESRD

\begin{tabular}{|c|c|c|c|c|c|c|}
\hline \multirow[b]{2}{*}{ Skale/Scales } & \multicolumn{6}{|c|}{ Zmienne/Variable } \\
\hline & $\begin{array}{l}\text { płeć/ } \\
\text { sex }\end{array}$ & $\begin{array}{c}\text { stan } \\
\text { cywilny/ } \\
\text { marital } \\
\text { status }^{*}\end{array}$ & $\begin{array}{l}\text { wiek/ } \\
a g e^{*}\end{array}$ & $\begin{array}{l}\text { wy- } \\
\text { kształce- } \\
\text { nie/ } \\
\text { educa- } \\
\text { tion }^{*}\end{array}$ & $\begin{array}{c}\text { przyczyna } \\
\text { niewydol- } \\
\text { ności } \\
\text { nerek/ } \\
\text { causes } \\
\text { of ESRD* }\end{array}$ & $\begin{array}{l}\text { sytuacja } \\
\text { ekonomiczna/ } \\
\text { economic } \\
\text { situation* }\end{array}$ \\
\hline $\begin{array}{l}\text { KDQoL } \\
\text { domeny/ } \\
\text { KDQoL } \\
\text { domain }\end{array}$ & $p$ & $p$ & $p$ & $p$ & 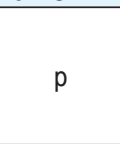 & $p$ \\
\hline KDQoL D1 & 0,709 & 0,361 & 0,395 & 0,417 & 0,180 & 0,756 \\
\hline KDQoL D2 & 0,579 & 0,548 & 0,420 & 0,084 & 0,010 & 0,146 \\
\hline KDQoL D3 & 0,884 & 0,200 & 0,200 & 0,990 & 0,350 & 0,305 \\
\hline KDQoL D4 & 0,838 & 0,179 & 0,084 & 0,022 & 0,317 & 0,624 \\
\hline KDQoL D5 & 0,941 & 0,054 & 0,960 & 0,042 & 0,557 & 0,370 \\
\hline KDQoL D6 & 0,889 & 0,189 & 0,019 & 0,130 & 0,981 & 0,267 \\
\hline KDQoL D7 & 0,918 & 0,165 & 0,007 & 0,075 & 0,515 & 0,351 \\
\hline KDQoL D8 & 0,661 & 0,089 & 0,484 & 0,975 & 0,025 & 0,046 \\
\hline KDQoL D9 & 0,855 & 0,610 & 0,047 & 0,230 & 0,532 & 0,977 \\
\hline KDQoL D10 & 0,936 & 0,951 & 0,892 & 0,175 & 0,945 & 0,776 \\
\hline KDQoL D11 & 0,826 & 0,533 & 0,521 & 0,390 & 0,209 & 0,818 \\
\hline \multicolumn{7}{|l|}{$\begin{array}{c}\text { SES } \\
\text { stwierdzenia/ } \\
\text { SES } \\
\text { statements }\end{array}$} \\
\hline SES 1 & 0,677 & 0,070 & 0,335 & 0,380 & 0,685 & 0,593 \\
\hline SES 2 & 0,776 & 0,095 & 0,188 & 0,291 & 0,485 & 0,698 \\
\hline SES 3 & 0,357 & 0,523 & 0,230 & 0,074 & 0,446 & 0,280 \\
\hline SES 4 & 0,936 & 0,016 & 0,172 & 0,001 & 0,902 & 0,183 \\
\hline SES 5 & 0,826 & 0,433 & 0,627 & 0,594 & 0,739 & 0,706 \\
\hline SES 6 & 0,764 & 0,123 & 0,073 & 0,277 & 0,632 & 0,580 \\
\hline SES 7 & 0,559 & 0,394 & 0,127 & 0,273 & 0,613 & 0,169 \\
\hline SES 8 & 0,222 & 0,479 & 0,597 & 0,320 & 0,107 & 0,034 \\
\hline SES 9 & 0,516 & 0,573 & 0,122 & 0,140 & 0,981 & 0,999 \\
\hline SES 10 & 0,645 & 0,381 & 0,310 & 0,172 & 0,816 & 0,755 \\
\hline $\begin{array}{l}\text { SES wynik/ } \\
\text { score }\end{array}$ & 0,461 & 0.102 & 0,216 & 0,158 & 0,607 & 0,978 \\
\hline
\end{tabular}

* test Manna-Whitneya, wartość $p$ istotna statystycznie $p<0,05$

Źródło: opracowanie własne

Source: author's own analysis

SES a poszczególne domeny KDQoL. Zależność z samooceną wykazano, analizując następujące domeny jakości życia: ciężar choroby nerek [D3; $r=(0,422)]$, funkcjonowanie poznawcze [D5; $r=(0,567)]$ oraz jakość stosunków międzyludzkich [D6; $r=(0,404)]$. Można zatem przypuszczać, że lepsze funkcjonowanie w ramach wyróżnionych domen KDQoL wiązało się z wyższą samooceną respondentów wg SES (Tabela 3). 
Tabela 3. Korelacje między skalami*

Table 3. Correlations between scales

\begin{tabular}{cc}
\hline KDQoLdomeny/KDQoL domains & SES wynik/SES score \\
\hline KDQoL D1 & $r=(0,057)$ \\
\hline KDQoL D2 & $r=(-0,032)$ \\
\hline KDQoL D3 & $r=(0,422) * * *$ \\
KDQoL D4 & $r=(0,026)$ \\
KDQoL D5 & $r=(0,567) * * *$ \\
KDQoL D6 & $r=(0,404) * * *$ \\
KDQoL D7 & $r=(0,026)$ \\
KDQoL D8 & $r=(0,013)$ \\
KDQoL D9 & $r=(0,235)$ \\
KDQoL D10 & $r=(-0,129)$ \\
KDQoL D11 & $r=(0,138)$ \\
\hline
\end{tabular}

${ }^{*} r$ - współczynnik korelacji rang Spearmana

***ilna zależność

Źródło: opracowanie własne

Source: author's own analysis

\section{Dyskusja}

Przeprowadzona w ramach badań własnych analiza jakości życia i samooceny dotyczyła 98 pacjentów leczonych metodą hemodializ. Skala KDQoL, którą posłużono się w badaniu, jest wieloprofilowym narzędziem pomiarowym, dostosowanym do oceny jakości życia pacjentów z określonymi, specyficznymi problemami zdrowotnymi, takimi jak ESRD. Natomiast wykorzystana do samooceny skala Rosenberga jest szczególnie przydatna, gdyż pozwala ocenić ogólny poziom poczucia własnej wartości. Uznaną zaletą tego narzędzia jest także to, że uzyskany wynik interpretuje się jako stały, a nie przejściowy stan. Ponadto przyjmuje się, że skala jest dobrym prognostykiem również innych aspektów samopoczucia psychicznego, takich jak niepokój czy depresja [9].

Biorąc pod uwage parametry socjodemograficzne i kliniczne oraz wyniki KDQoL, stwierdzono, że chorzy dializowani uzależniali swoją jakość życia w głównej mierze od wieku i ogólnej codziennej aktywności, związanej z wykształceniem oraz przyczyną choroby nerek. Potwierdzają to wcześniejsze prace $[5,16,17]$. Leczenie nerkozastępcze wpływało $\mathrm{w}$ dominującym stopniu na styl życia i codzienne funkcjonowanie zarówno badanych pacjentów, jak i ich rodzin. Podporządkowanie schematowi leczenia wszelkich czynności, w tym zawodowych, zakłócało możliwości kontynuowania zatrudnienia i uzyskiwania dochodu; do podobnych wniosków doszli Zhang i wsp. oraz Gentile [17, 18]. Gorsza jakość życia była ewidentnie związana z niskim wskaźnikiem zatrudnienia, $87 \%$ badanych stanowiły osoby niepracujące, w tym $21,5 \%$ chorych musiało z przyczyn zdrowotnych zrezygnować z pracy zawodowej, a $37 \%$ było na rencie chorobowej. Konieczność zaprzestania pracy zawodowej może wynikać, po pierwsze, z dezorganizujących plan dnia zabiegów hemodializ oraz, po drugie, z faktu, że pacjenci z ESRD często już nie są w stanie podjąć ponownego zatrudnienia z powodu zaawansowania choroby lub obecności schorzeń współistniejących, np. cukrzycy, choroby niedokrwiennej serca, co wiąże się z koniecznością sprawowania opieki przez rodzinę $[15,18]$.

Dotychczasowe, dość nieliczne badania dotyczące samooceny pacjentów dializowanych wskazują, że ta grupa chorych ma niższą samoocenę w porównaniu do zdrowej populacji [19]. Wyniki badań własnych wykazały jednak, że $62 \%$ pacjentów nie miało niskiej samooceny. W przeprowadzonych badaniach stwierdzono istnienie dodatniej korelacji pomiędzy samooceną a jakością życia. Tym samym można przypuszczać, że badani, których cechowała dobra samoocena wyżej oceniali jakość życia. Ten zadowalający wynik może wynikać z przekrojowego charakteru badania, stosunkowo nielicznej grupy lub też obecności wśród badanych osób o krótkim okresie dializowania. Ponadto może oznaczać konstruktywne psychofizyczne zaangażowanie pacjentów w skuteczne kontrolowanie choroby. Argumentację tę podzielają także inni autorzy [19-24], którzy ponadto w swych badaniach podkreślają znaczenie związku ogólnej samooceny, samopoczucia psychicznego, emocjonalnego i szacunku do samego siebie z jakością życia u chorych hemodializowanych. Podobnie jak Quinan [25] można potwierdzić ścisłą relację pomiędzy samooceną pacjentów a obecnością przewlekłej choroby nerek stwierdzeniem, że zrozumienie choroby i jej następstw wpływa nie tylko na skuteczność leczenia, poczucie troski i kontroli osobistej, ale również na składowe samooceny, takie jak postrzeganie siebie i własnej tożsamości, a to z kolei istotnie rzutuje na jakość życia.

W rezultacie, rozważając pewne propozycje poprawy jakości życia pacjentów z ESRD, należałoby wziąć pod uwagę następujące czynniki: po pierwsze, punkt widzenia pacjenta z chorobą przewlekłą, czasem całkowicie odmienny od stanowiska profesjonalistów medycznych, których postawa jest przesiąknięta doświadczeniami klinicznymi. Zatem spojrzenie na chorobę z perspektywy pacjenta, zrozumienie jego indywidualnej psycho-fizyczno-społecznej sytuacji życiowej i ogólnej kondycji zdrowotnej umożliwi konstruktywna komunikacja pomiędzy pacjentem a całym zespołem terapeutycznym, a to zwiększy poczucie komfortu chorego w codziennym życiu. Po drugie, subiektywną ocenę pacjenta, rozważaną przy podejmowaniu różnych decyzji leczniczych, dających niejednokrotnie te same wyniki w znaczeniu somatycznym, jednakże w różnym stopniu rzutujące na późniejszą jakość życia 
Po trzecie, zainteresowanie problemami i potrzebami pacjentów poza środowiskiem szpitalnym, co daje chorym szczególne poczucie bezpieczeństwa [26]. W środowisku domowym podstawowym warunkiem zapewnienia odpowiedniej jakości życia pacjenta, który musi aktywnie uczestniczyć w procesie leczenia, jest edukacja. Zdobycie przez chorego wiedzy i umiejętności w zakresie samokontroli i interpretacji parametrów własnego zdrowia, nauka zasad żywienia w okresie dializoterapii, zapobieganie powikłaniom, np. groźnym zakażeniom dostępu naczyniowego, warunkują skuteczne radzenie sobie $z$ chorobą. Ponadto warunki pozaszpitalne są również wyzwaniem dla pracy psychospołecznej z chorym, czyli pomocy w akceptacji choroby i związanych z nią ograniczeń, zwiększenia motywacji do ścisłego przestrzegania zaleceń, a także wskazywania na możliwości uzyskiwania odpowiedniego wsparcia socjalnego, będącego integralną składową szeroko pojętej jakości życia [26-28].

\section{Wnioski}

1. Dializoterapia jako forma leczenia przewlekłej niewydolności nerek w dużym stopniu zmienia styl i jakość życia pacjentów.

2. Samoocena ma związek $z$ jakością życia chorych leczonych nerkozastępczo i u znacznej części badanych pacjentów nie miała wymiaru negatywnego.

3. Wyniki z wykorzystaniem skali KDQoL i SES sugerują potrzebę przeprowadzenia dalszych podłużnych badań w dużych grupach.

Istniały pewne ograniczenia w badaniu, tj. grupa badana małych rozmiarów i krótki okres badania. W związku z tym zaleca się przeprowadzenie dalszych badań o większym rozmiarze i w dłuższym okresie obserwacji.

\section{Piśmiennictwo}

1. Zyoud SH, Daraghmeh DN, Mezyed OD, Khdeir RL, Sawafta MN, Ayaseh NA, Tabeeb GH, Sweileh WM, Awang R, Al-Jabi SW. Factors affecting quality of life in patients on haemodialysis: a cross-sectional study from Palestine. BMC Nephrol. 2016; 17(1): 44.

2. Saban KL, Bryant FB, Reda DJ, Stroupe KT, Hynes DM. Measurement invariance of the kidney disease and quality of life instrument (KDQOL-SF) across Veterans and nonVeterans. Health Qual Life Outcomes. 2010; 8: 120, http:// www.hqlo.com/content/8/1/120 (data dostępu: 2.10.2016).

3. Borrelli S, Minutolo R, De Nicola L, De Simone W, De Simone E, Zito B, Di lorio BR, Di Micco L, Leone L, Bassi A, Romano A, Porcu MC, Fini R, Vezza E, Saviano C, D’Apice L, Simonelli R, Bellizzi V, Palladino G, Credendino O, Genualdo R, Capuano M, Guastaferro P, Nigro F, Stranges V, luianiello G, Russo FS, Auricchio MR, Treglia A, Palombo P, Rifici N, Nacca R, Caliendo A, Brancaccio S, Conte GG. Quality of life of hemodialysis patients in Central and Southern Italy: cross-sectional comparison between Hemodiafiltration with endogenous reinfusion (HFR) and Bicarbonate Hemodialysis. G Ital Nefrol. 2016; 33(3), pii: gin/33.3.8.
4. Sumskiene J, Kupcinskas L, Sumskas L. Health-related quality of life measurement in chronic liver disease patients. Medicina (Kaunas). 2015; 51(4): 201-208.

5. Gentile S, Jouve E, Dussol B, Moal V, Berland Y, Sambuc R. Development and validation of a French patient-based health-related quality of life instrument in kidney transplant: the ReTransQoL. Health Qual Life Outcomes. 2008; 6: 78.

6. KDQOL Clinical Practice Guidelines for Chronic Kidney Disease: Evaluation, Classification and Stratification. National Kidney Fundation. Am J Kidney Dis. 2002; 39: 1 Suppl.: S1-S266.

7. Hays RD, Kallich JD, Mapes DL, Coons SJ, Carter WB. Development of the kidney disease quality of life (KDQOL) instrument. Qual Life Res. 1994; 3(5): 329-338.

8. Rosenberg M. Society and the adolescent self-image. Princeton: Princeton University Press; 1965.

9. Dzwonkowska I, Lachowicz-Tabaczek K, Łaguna M. Samoocena i jej pomiar. Warszawa: Pracownia Testów Psychologicznych; 2008. 13-17.

10. Costa VF, Alves SG, Eufrásio C, Salomé GM, Ferreira LM. Assessing the body image and subjective wellbeing of ostomists living in Brazil. Gastrointestinal Nurs. 2014; 12: 37-47.

11. Kusztal M, Nowak K, Magott-Procelewska M, Weyde W, Penar J. Evaluation of health-related quality of life in dialysis patients. Personal experience using questionnaire SF-36. Pol Merk Lek. 2003; 14(80): 113-117.

12. Salomé GM, de Almeida S, Silveira M. Quality of life and self-esteem of patient with renal disease. J Coloproctol. 2014; 34(4): 231-239.

13. Salomé GM, de Almeida SA. Association of sociodemographic and clinical factors with the self-image and selfesteem of individuals with intestinal stoma. J Coloproctol. 2014; 34: 159-66.

14. Danquah FVN, Wasserman J, Meininger J, Bergstrom N. Quality of life measures for patients on hemodialysis: A review of psychometric properties. Nephrol Nurs J. 2010; 37(3): 255-270.

15. Sapilak BJ, Kurpas D, Steciwko A, Melon M. Czy jakość życia jest istotna dla chorych dializowanych? Na podstawie 3-letniej obserwacji pacjentów. Probl Lek. 2006; 43(3): 89-93.

16. Gómez-Besteiro MI, Santiago-Pérez MI, Alonso-Hernández A, Valdés-Cañedo F, Rebollo-Alvarez P. Validity and reliability of the SF-36 questionnaire in patients on the waiting list for a kidney transplant and transplant patients. Am J Nephrol. 2004; 24: 346-351.

17. Gentile S. Principal determinants of quality of life. Soins. 2004; Suppl. 688: 4.

18. Zhang AH, Cheng LT, Zhu N, Sun LH, Tao Wang T. Comparison of quality of life and causes of hospitalization between hemodialysis and peritoneal dialysis patients in China. Health Qual Life Outcomes. 2007; 5: 49.

19. Poorgholami F, Javadpour S, Saadatmand V, Jahromi MK. Effectiveness of Self-Care Education on the Enhancement of the Self-Esteem of Patients Undergoing Hemodialysis. Glob J Health Sci. 2016; 8(2): 132-136.

20. Sertoz OO, Asci G, Toz F, Duman S, Elbi H, Ok E. Planning a social activity to improve psychological well-being and quality of life of hemodialysis patients: a pilot study. Ther Apher Dial. 2009; 13(4): 366-372.

21. Lii YC, Tsay SL, Wang TJ. Group intervention to improve quality of life in haemodialysis patients. J Clin Nurs. 2007;16(11C): 268-275.

22. Wong FK, Chow SK, Chan TM. Evaluation of a nurse-led disease management programme for chronic kidney disease: a randomized controlled trial. Int J Nurs Stud. 2010; 47(3): 268-278. 
23. Vicdan AK, Karabacak BG. Effect of Treatment Education Based on the Roy Adaptation Model on Adjustment of Hemodialysis Patients. Clin Nurse Spec. 2016; 30(4): 1-13.

24. Ivasere OU, Brown EA, Johansson L, Huson L, Smee J, Maxwell AP, Farrington K, Davenport A. Quality of Life and Physical Function in Older Patients on Dialysis: A Comparison of Assisted Peritoneal Dialysis with Hemodialysis. Clin J Am Soc Nephrol. 2016; 11(3): 423-430.

25. Quinan P. Control and coping for individuals with end stage renal disease on hemodialysis: a position paper. CANNT J. 2007; 17(3): 77-84.

26. Uchmanowicz I, Uchmanowicz B, Jankowska-Polańska B, Tymoczko I. Jakość życia zależna od zdrowia - generyczne kwestionariusze badawcze. W: Rosińczuk-Tonderys J, Uchmanowicz I (red.). Chory przewlekle - aspekty pielęgnacyjne, rehabilitacyjne, terapeutyczne. Wrocław: MedFarm; 2013. 41-50.

27. Boini S, Frimat L, Kessler M, Briancom S, Thilly N. Predialysis therapeutic care and health-related quality of life at dialysis onset (The pharmacoepidemiologic AVENIR study). Health Qual Life Outcomes. 2011; 9: 7 .
28. Fowler C, Baas LS. Illness representations in patients with chronic kidney disease on maintenance hemodialysis. Nephrol Nurs J. 2006; 33(2): 173-164, 179-186.

Artykuł przyjęty do redakcji: 15.11 .2016

Artykuł przyjęty do publikacji: 19.12.2016

Źródło finansowania: Praca nie jest finansowana z żadnego źródła. Konflikt interesów: Autorzy deklarują brak konfliktu interesów.

Adres do korespondencji:

Magdalena Strugała

ul. Heliodora Święcickiego 6

60-781 Poznań

tel.: 618546487

e-mail: magdastrugal@ump.edu.pl

Pracownia Pielęgniarstwa Społecznego

Katedra i Zakład Profilaktyki Zdrowotnej

Uniwersytet Medyczny im. Karola Marcinkowskiego w Poznaniu 